\title{
Siyah Kuğuyu Yönetmek
}

\author{
DOI: $10.26466 /$ opus. 686105
}

$*$

\author{
Mehmet İnce* - Onur Başar Özbozkurt ${ }^{* *}$ \\ * Prof. Dr., Tarsus Üniversitesi, Uygulamalı Bilimler Fakültesi, Mersin/Türkiye \\ E-Posta: mince@tarsus.edu.tr \\ ORCID: $0000-0003-0612-3688$ \\ ** Dr. Öğr. Üyesi, Tarsus Üniversitesi, Meslek Yüksekokulu, Mersin/Türkiye \\ E-Posta: onurozbozkurt@tarsus.edu.tr \\ ORCID: 0000-0002-2325-2433
}

\section{Öz}

Tahmin edilemeyen ve risk analizi yapılmasına karşın öngörülemeyen olaylarn ifade eden "Siyah Kuğu", Taleb (2007) tarafindan literatüre kazandırlmakla birlikte dünya genelinde akademik anlamda dikkat çeken bir metafor haline gelmiştir. Ancak, Türkçe literatürde yeterli ilgiyi görmemiş ve herhangi bir bilimsel araştırmaya konu olmamıştır. Bu açıdan bu çalışma, özellikle Türkçe literatürdeki eksikliğin giderilmesi ve stratejik yönetim sürecinde dikkat edilmesi gereken siyah kuğularm doğru bir şekilde yönetilerek, yöneticilere yeni bir perspektif sunması amacıyla gerçekleştirilmiştir. Bu amaç doğrultusunda bu çalışmada, risklerin planlanması ve yönetilmesinde, gerçekçi olmayan beklentilerden uzak durulması, olasılık alanlarının net bir şekilde belirlenerek stratejilerin bu yönde geliştirilmesi, siyah kuğulara karşı körlüğ̈̈n oluşmaması için siyah kuğuların daima farkında olarak gerek iç gerekse dış çevre analizinin yapılması, dogmatik bir perspektif ile stratejilerin oluşturulmasından kaçınarak, her olasılı̆̆ın meydana gelebileceği bilinciyle stratejilerin formüle edilmesi ve pozitif siyah kuğulara daima açık, negatif siyah kuğulara karşı ise proaktif davranarak gerekli önlemlerin alınması gibi hususların, siyah kuğunun stratejik yönetiminde önem arz ettiği görülmüştür.

Anahtar Kelimeler: Siyah kuğu, siyah kuğu körlüğ̈̈, olasıllk, belirsizlik, risk 


\title{
Managing the Black Swan
}

\begin{abstract}
"Black Swan", which refers to unpredictable and unforeseen events despite analyzing risks, has academically become a remarkable metaphor worldwide that was brought to the literature by Taleb (2007). However, the topic has received little attention in Turkish literature so far and has not been scientifically studied. In this regard, this study has been carried out within the purpose of being fulfilled a clear need of research specifically in Turkish literature and offered a new perspective to managers via appropriately managing black swans that is a noteworthy point in the strategic management process. For this purpose, it has been seen in the study that the matters such as being avoided unrealistic expectations, developed strategies via clearly determining and understanding of the space of possibilities in the planning and managing risks, analyzed both internal and external environment via being aware of black swans for preventing black swan blindness, formulated strategies within the awareness of taking into account every possibilities via avoiding the creation of strategies with dogmatical perspective, and open for positive black swans and taken necessary measures via behaving proactive to negative black swans have been remarked.
\end{abstract}

Keywords: Black swan, black swan blindness, probability, uncertainty, risk. 


\section{Giriş}

Tahmin edilemeyen ve öngörülemeyen olayların yarattı̆̆ olağanüstü etkiler, işletmeleri siyah kuğu olarak nitelendirilen güncel metafora karşı artan oranda savunmasız birakmaktadır (Poonawala, 2016, s.1). Siyah kuğular; beklenen ve deneyimlenen modellerin aksine, benzersiz ve tesadüfi bir şekilde gelişen, yüksek etkiye sahip olan ve tahmin edilemeyen olayları nitelemektedir (Peters ve McKay, 2014, s.213). Farklı bir ifadeyle, gerçekleşmesi az olasillkla muhtemel bir durumu ifade etmekte olup (Taleb ve Blyth, 2011, s.36; Brunåker ve Nordqvist, 2013, s. 8; Ponkin, 2019, s. 10); doğası gereği "aykırı" bir değer olarak tanımlanmakta ve "uç" bir etkiye sahip olmaktadır (Lindaas ve Pettersen, 2016, s.1232).

Siyah kuğu metaforu, ilk olarak 1697 yılında Avustralya'da tüm kuğuların beyaz olduğu görüşünün aksine siyah kuğuların beklenmedik bir şekilde keşfedilmesiyle ortaya çıkmıştır (Runde, 2009, s.493). Bilimsel anlamda ise siyah kuğu metaforu, ilk kez Taleb (2007) tarafından gerçekleştirilmiş olan "The Black Swan-The Impact of Highly Probable" başlıklı eserde ele alınmasina ve küresel düzeyde dikkat çeken bir metafor haline gelmesine (Nafday, 2009, s.192) rağmen, Türkçe literatürde Taleb (2007)'e ait çalışmanın Türkçe versiyonunun haricinde akademik anlamda herhangi bir çalışmaya rastlanılamamıştır. Buradan hareketle bu çalışma, özellikle Türkçe literatürdeki eksikliğin giderilmesi ve risk ile belirsizlik kavramlarıyla yakından ilişkili olan siyah kuğuların stratejik yönetiminde, yöneticilere yeni bir perspektif sunulması amaciyla gerçekleştirilmiştir.

\section{Siyah Kuğu Kavramı ve Kapsamı}

\section{Bir metafor olarak siyah kuğu}

Günümüz iş dünyasında yaşanılan ekonomik durum ve koşullar, işletmelerin uzun vadeli getirilerini yönetmekte olup; finansal sistemin başlıca katılımcılarının duygusal faktörleri, ekonomik koşulların merkezini değiştirebilmekte ve böylesine bir ortamda siyah kuğu yaklaşımı ortaya çıkmaktadır (Bogle, 2008, s.34). Bu açıdan ilgili literatür göz önünde bulundurulduğunda, siyah kuğunun özellikle, 2007 yılında Nassim Nicholas Taleb tarafından ya- 
yınlanmış olan "The Black Swan-The Impact of Highly Probable" başlıklı eseriyle birlikte küresel düzeyde dikkat çeken bir metafor haline geldiği vurgulanmaktadır (Nafday, 2009, s.192; Flage ve Aven, 2015, s.63).

Taleb $(2007$, s.2) siyah kuğu metaforunu, tahmin edilemeyen, daha az öngörülebilen ve büyük etki yaratan olaylar olarak tanımlamaktadır. Farklı bir ifadeyle, siyah kuğu, bilinmeyen bilinmeyenler, bilinmeyen bilinenler ve meydana gelebileceğine olanak verilmeyen durumlar (Aven, 2015, s.83) veya bütünüyle bilinmeyen, risk analizi yapılmasına karşın açıkça öngörülemeyen ve gerçekleştirilen risk analizinde bilinen ve öngörülen olaylar olarak dikkat çekmektedir (Aven ve Krohn, 2014, s.9).

Maslen ve Hayes (2015, s. 1247) ile Forsman (2018, s.12)'a göre siyah kuğu yaklaşımı, beklenmeyen ve gerçekleşmesi halinde büyük çaplı etki yaratan olayları nitelemekte ve en önemlisi, mevcut bilgileri göz önünde bulundurarak bir duruma ya da olaya hâkim olan bireyler tarafından dahi öngörülmesi güç olmaktadır. Mueller ve Stewart (2016, s.1319) da benzer şekilde siyah kuğuyu, beklenmeyen ve dikkat çekici bir şekilde etki yaratan, tahmin edilemeyen olayların bütünü olarak ifade etmektedir.

Yanı sira, Stodd, Reitz, Schatz ve Fautua $(2016$, s.1) siyah kuğuyu, bilinmeyen, doğası gereği tahmin edilemeyen, başlangıçta net olmayan bir anlayış ve kavram olarak tanımlamakta ve siyah kuğunun, içselleştirilmiş yanlış bilinen bilgilere yeni bir bakış açısı getirilmesinde kritik bir unsur olduğuna dikkat çekmektedir. Buradan hareketle, siyah kuğu; öngörülebilir olmayan, olağanüstü bir etkiye sahip olan ve beklenmedik olmasına rağmen ortaya çıtıktan sonra açıklanabilir bir gerekçeye sahip olmayı içeren üç temel bileşenden oluşmaktadır (Karadimas, Hewig, Behera ve Kotisi, 2014, s.2). Bu bağlamda bilinmeyen bilinmeyenler, bilinmeyen bilinenler ve gerçekleşmesine inanılmayan olayları ifade eden siyah kuğu metaforunun şematik gösterimine Şekil 1'de yer verilmiştir. 


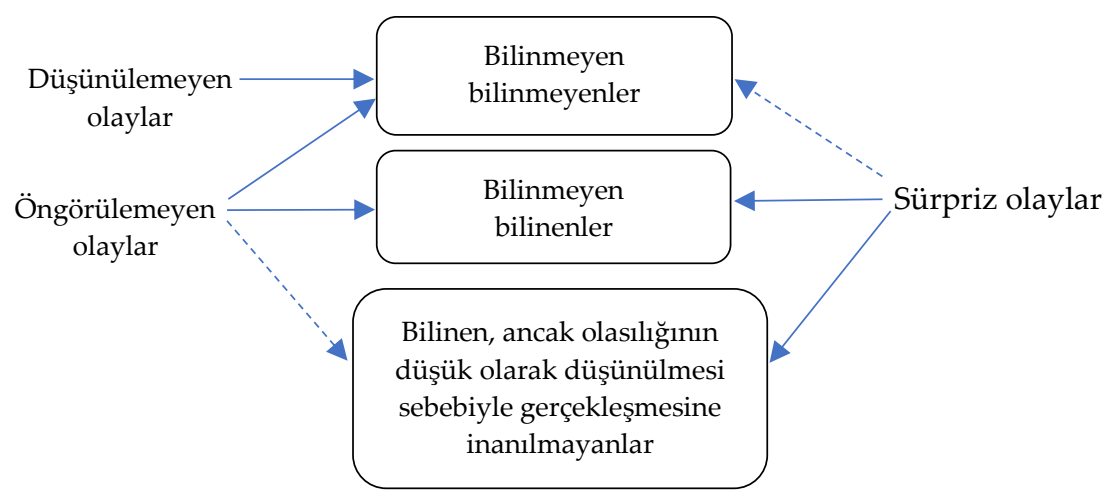

Şekil 1. Siyah Kuğu Metaforu, Aven (2017, s. 29)'den uyarlanmıştır.

Bu çerçevede, "bilinmeyen bilinmeyenler", toplum tarafından düşünülemeyen, uç noktadaki olayları ifade etmektedir. "Bilinmeyen bilinenler", organizasyonlarda, risk analizinin doğru yapılmadığı ve stratejistlerin gözden kaçırdığı durum ve olayları nitelemektedir. Farklı bir ifadeyle, daha ayrıntılı bir analizin gerçekleşmesi durumunda, karşılaşılması muhtemel olayların tanımının yapılabilmesinin mümkün olduğu durumları temsil etmektedir. "Bilinen, ancak olasılığının düşük olarak düşünülmesi sebebiyle gerçekleşmesine inanılmayanlar" ise olayların bilindiği, ancak gerçekleşmesine ihtimal verilmediği için herhangi bir önlem alınmayarak, göz ardı edilmesini kapsamaktadır (Aven ve Krohn, 2014, s. 9; Aven, 2017, s. 29).

\section{Siyah Kuğu Metaforuna İlişkin Temel Olaylar}

Hollandalı Willem de Vlamingh'in 1697 yılında Avustralya'yı keşfetmesinden önce Avrupalılar bütün kuğuların beyaz olduğuna inanmıştır. Ancak, Vlaming, beyaz kuğular kadar dikkat çeken koyu tüylü siyah kuğuları fark etmiş ve böylece, o tarihe kadar öngörülemeyen siyah kuğular, Avrupalıların "siyah kuğu" kavramı üzerinde odaklanmasına zemin hazırlamıştır (Taleb, 2007, s.15; Blight ve Lang, 2013, s.4; Gardner, 2017, s.3; Roland, 2017, s.823; Santoli ve Siebenbrunner, 2018, s.2). Buna ek olarak, 11 Eylül 2001 tarihinden iki ay öncesine kadar New York Times, terör tehdidinin giderek azaldığını ve artık yaygın olmadığını ve tüm dünyada Amerika Birleşik Devletleri'nin gü- 
venlik bağlamında ön plana çıkan bir süper güç olduğunu ifade etmesine karşın, "11 Eylül Olayları" olarak nitelenen, Dünya Ticaret Merkezi'ne gerçekleştirilen saldırılar ise negatif siyah kuğu metaforunun önemini gözler önüne sermiştir (Aik ve Xiang, 2016, s.61).

Diğer taraftan, Google, Apple, Microsoft gibi küresel değer zincirlerinin önemli bir bölümünü oluşturan şirketlerin olağanüstü başarısının (Mahroum, 2015, s. 48), siyah kuğu metaforu açısından çarpıcı örnekler olarak ön plana çıktığı görülmektedir. Bu kapsamda, Google'ın küresel ekonomiye hâkim olarak böylesine yüksek hacimde başarı elde edeceğini kimsenin öngörememesi (Taleb, 2007, s.2; Arnas, 2009, s.241-242), Apple stratejistlerinin dinamik işletme modelini benimsemesiyle devrim yaratan nitelikte ürünler üretmesi ve insanların iletişim kurma yöntemlerini tahmin edilemeyen bir şekilde tamamen değiştirmesi (Andersen ve Poulfelt, 2014, s.5-6) ve Microsoft'un kişisel bilgisayar devrimi gerçekleştirerek radikal bir başarı elde etmesi (Sarriot, 2009, s.9), en önemli pozitif siyah kuğu örnekleri arasında yerini almaktadır.

\section{Siyah Kuğu Yönetim Stratejileri}

Siyah kuğu yaklaşımı belirsizlik ve belirsizliği öğrenme kavramlarıyla yakından ilişkili olmakla birlikte, organizasyonlarda siyah kuğuların, en uygun stratejilerle yönetilmesinin, organizasyonların sürdürülebilirliği noktasında hayati öneme sahip olduğu vurgulanmaktadır (Hajikazemi, Ekambaran, Andersen ve Zidane, 2016, s.184-185). Farklı bir ifadeyle, siyah kuğunun, organizasyonlarda uygulanan alternatif stratejilerin belirlenmesi ve organizasyonların başarılarının artırılması yönündeki bilginin keşfedilmesine öncülük ettiği düşünülmektedir (Catalano, Redfort, Margoluis ve Knight, 2017, s.588).

Diğer taraftan, organizasyonlar, piyasa, işletme, finansal ve stratejik riskler gibi bilinen risklere odaklanırken, öngörülemeyen ve bilinemeyen siyah kuğu riskleri konusunda daha az çaba harcamaktadır (Petty, 2012, s.21). Nitekim, Kennon ve Schutte (2015, s.69)'ye ait, organizasyonların stratejik yönetiminde göz ardı edilmemesi gereken siyah kuğuların şematik gösterimine Şekil 2'de yer verilmiştir. 


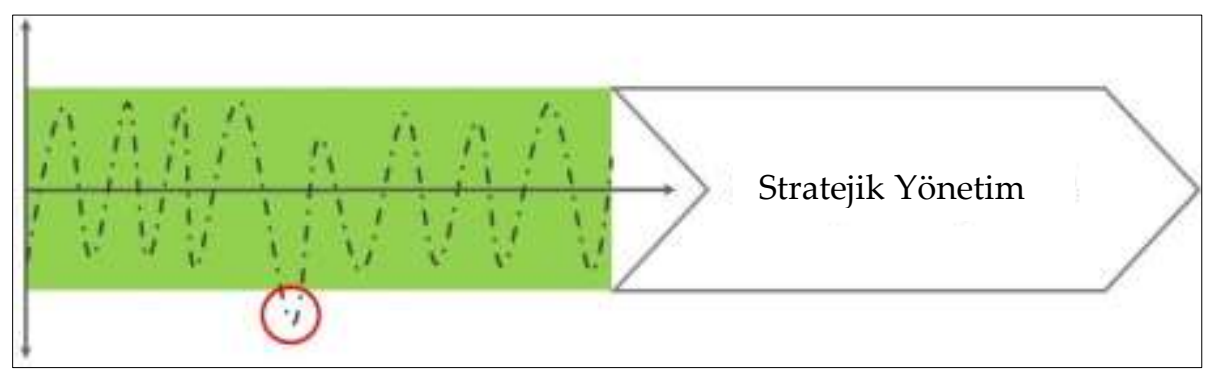

Şekil 2. Stratejik Yönetim Sürecine Dahil Edilmesi Gereken Siyah Kuğunun Şematik Gösterimi, Kennon ve Schutte (2015, s. 69)'den uyarlanmıştır.

Buradan hareketle, Taleb (2007, s.50), siyah kuğulara karşı körlüğü oluşturan beş temel insan davranışına dikkat çekmektedir:

- Bireyler öncelikle, çelişkiye karşıt olma, kendi inançlarını teyit etme ve seçici bilgiye odaklanarak bu bilgiyi kategorize etme; farklı bir ifadeyle, bir fikir hakkında olumlu bir görüş oluşturduktan sonra bu görüşle çelişecek bilgilere değer vermeme (confirmation bias) eğiliminde olmaktadir.

- Bireyler, anlatı yanilgisina (narrative fallacy) kapılarak olay ve durumları açıklayabilmek üzere gerekçeler inşa etmektedir.

- İnsan doğasında siyah kuğuyu hayal etmek bulunmamaktadır.

- Bireyler gerek başarıya gerekse başarısızlığa orantısız bir şekilde odaklanmakta ve gözlemlenmemiş, farklı bir ifadeyle sessiz kanitları göz ardı etme eğiliminde olmaktadır.

- Son olarak ise, tünel vizyonu (tunnel vision) olarak ifade edilen, bireyin bir bilgi veya uzmanlık alanına olduğundan fazla değer biçmesi ve belirsizliğin diğer kaynaklarını göz ardı etmesi ve gerçeğe aykırı bir kurgu oluşturması (ludic fallacy), körlüğe neden olmaktadır. Başka bir deyişle, tünel vizyonunun etkisiyle belirsizliğin bilinen kaynaklarına odaklanıp, gerçeğin karmaşıklığını göz ardı etmektedir.

Farklı bir ifadeyle, yöneticilerin, olası geleceği düşünürken ve bununla ilgili kararlar alırken, gerçekleşme ihtimali daha yüksek olan olaylara odaklanması ve gerçekleşme ihtimali daha düşük olayları göz ardı edebilmesi, stratejik başarısızlıklara sebep olabilmektedir. Nitekim, dünyanın en büyük işletmelerinin almış oldukları kararlarda dahi çok yüksek başarısızlık oranlarının gözlemlendiği dikkat çekmiştir. Örneğin, PwC (2004) tarafından 30 ülkedeki 
çeşitli sektörlerde 200 'den fazla firmanın üzerinde gerçekleştirilen araştırmada, işletmecilik faaliyetlerinde alınan kararların yalnızca \%2,5'inin tamamen başarılı olduğu tespit edilmiştir (Mezias ve Starbuck, 2008, s. 77-81). Dahası, Baumard ve Starbuck (2005, s. 282)'ın dev işletmelerin yöneticileri üzerinde gerçekleştirdikleri çalışmasında, işletmelerde alınan kararlardaki stratejik başarısızlıkların yöneticilerin kendileri ile ilgili olmadığı, öngörülemeyen dışsal etmenler sebebiyle bu başarısızlıkların ortaya çıktığı ifade edilmiş ve yapılan hataların büyüklügünün artması durumunda yöneticilerin bu hataların kaynaklarını daha fazla oranda dışsal sebebe bağladığı ve gerekçelendirme eğiliminde bulunduğu tespit edilmiştir. $\mathrm{Bu}$ ise, tünel vizyonunun bir sonucu olan siyah kuğu körlüğü oluşumu ile açıklanabilmektedir.

\section{Sonuç}

İşletmelerin etkililiği, çevresel faktörlerin analizi ve optimum iş stratejilerinin ortaya koyularak bu faktörlerin her ikisinin de doğru bir şekilde yönetilmesine bağlıdır. Bu açıdan başarı, iç ve dış çevrenin özellikle siyah kuğuların da dahil edilerek doğru bir şekilde analiz edilmesi ve bu bağlamda oluşturulan alternatif stratejilerin bir sonucu olarak ortaya çıkmaktadır. Farklı bir ifadeyle, kurumsal stratejilerin planlanması ve belirlenmesinde hem iç hem de dış çevrenin analizinden faydalanılabilmekte olup; böylesine bir yaklaşımla işletme doğru bir pozisyon alabilecek, sahip olduğu özgün yetkinlikleri ile tüm tehditleri avantaj haline getirebilecek ve rekabet gücünü artıracaktır (Indris ve Primiana, 2015, s.188-189). Bu anlamda, ortaya çıan sistematik riskler ve beklenmeyen olaylarla ilişkili belirsizlikler göz önünde bulundurulduğunda, özellikle risklerin planlanması ve yönetilmesi noktasında, gerçekçi olmayan beklentilerden uzak durulması ve olasılık alanlarının net bir şekilde belirlenerek stratejilerin bu yönde geliştirilmesi önem arz etmektedir (Masys, 2012, s.320).

Organizasyonlar, siyah kuğunun stratejik yönetiminde bazı temel noktaları göz önünde bulundurmalı ve organizasyonel sürdürülebilirliğe olanak sağlamalıdır. Bu bağlamda, yöneticiler, siyah kuğulara karşı körlüğün oluşmaması için siyah kuğuların daima farkında olarak gerek iç gerekse dış çevre analizine önem vermelidir. Ek olarak, organizasyonlar, özellikle stratejik yönetim sürecinde, kanıtlar olsa dahi, olay ve olguları yeniden sorgulamaya eği- 
limli olmalı ve yanılabilmenin her alanda mümkün olabileceğini kabullenmelidir (www.economist.com). Yanı sıra, yapılan hata ve yanlış stratejik hamlelerin tehlikeli sonuçları olabileceği gibi, iyi sonuçlarının da var olduğu bilincine sahip olmalıdır (Van Dyck, Frese, Baer ve Sonnentag, 2005, s.1228).

Diğer taraftan, tahminleme sürecinin uzun sürmesi durumunda, tahminlemede yapılan hataların da katlanarak artabileceğinden hareketle, kanitların olmadığı durumlarda tahminlemeyi askıya alarak sonuçlara odaklı bir yönetim anlayışının benimsenmesine önem verilmelidir. Bu açıdan, organizasyonların, pozitif siyah kuğulara daima açık olması, negatif siyah kuğulara karşı ise proaktif davranarak önlem alması gerekmektedir. Bununla birlikte, organizasyonlar, kanitları toplayarak elde bulundurmaya odaklanmak yerine, öngörülemeyen durum ve olaylara ağırlık vererek, karşılaşılması muhtemel olaylara dikkat etmeli; doğrulayıcı kantların daima bir teori veya bir olguyu kanıtlamayacağını göz önünde bulundurmalıdır. Bu açıdan, organizasyonlar, dogmatik bir perspektif ile stratejilerin oluşturulmasından kaçınarak, stratejilerini, yenilikçi ve her olasılığın meydana gelebileceğinin bilincine sahip bir şekilde ortaya koyarak uygulamaya odaklanmalıdır (www.economist.com). Buradan hareketle, siyah kuğu yaklaşımının taşımakta olduğu önem göz önünde bulundurulduğunda, stratejistlerin alternatif stratejileri formüle ederken öngörülemeyen ancak karşılaşılma olasılığı olan riskleri de dikkate alması gerekliliğinin, gelecekte, organizasyonel başarının sağlanması ve sürdürülebilir bir rekabet avantajının elde edilmesinde daha merkezi bir role sahip olacağı çıkarımında bulunulabilmektedir. 


\section{EXTENDED ABSTRACT}

\section{Managing the Black Swan \\ * \\ Mehmet İnce - Onur Başar Özbozkurt \\ Tarsus University}

Extraordinary effects that were caused by unpredicted and unforeseen events, exponentially leave organizations vulnerable to black swans that refer to current metaphor (Poonawala, 2016, p.1). Black swans represent unique and random events, highly impactful, and unpredicted events, on the contrary, it is divorced from previous experience and unanticipated by any previous models (Peters and McKay, 2014, p.213). In other words, it states a small number of possible events dominate (Taleb and Blyth, 2011, p.36; Brunåker and Nordqvist, 2013, p. 8; Ponkin, 2019, p. 10); is defined as by its very nature an "outlier" and has an "extreme" impact (Lindaas and Pettersen, 2016, p.1232).

Prior to the first recorded sighting of black swans in Australia in 1697, the accumulated evidence pointed to all swans being white (Runde, 2009, p.493). Although the metaphor of black swan was examined in the publication of "The Black Swan-The Impact of the Highly Improbable" coined by Taleb (2007) in scientific context and globally remarked as a metaphor (Nafday, 2009, p.192), the topic has received little attention in Turkish literature so far except the Turkish version of Taleb (2007)'s research and has not been scientifically studied. From this point of view, the study has been carried out within the purpose of being fulfilled a clear need of research specifically in Turkish literature and offered a new perspective to managers via appropriately managing black swans that is a noteworthy point in the strategic management process.

The economic conditions experienced in today's business world determine the long-term returns of businesses; the emotional factors of the fundamental participants of the financial system may change the focus of economic conditions and a black swan may appear at any time in this business environment (Bogle, 2008, p.34). Taking into consideration the related literature, black swan has been emphasized as a remarkable metaphor worldwide that 
was originally introduced in the publication of "The Black Swan-The Impact of the Highly Improbable" by Nassim Nicholas Taleb in 2007 (Nafday, 2009, p. 192; Flage and Aven, 2015, p. 63).

Taleb (2007, p. 2) describes that a black swan metaphor refers to unpredictable, less random, and massive impact events. In other words, black swan has been drawn attention as unknown unknowns, unknown knowns, and events that are judged to have a negligible probability of occurrence and therefore are not believed to happen (Aven, 2015, p. 83) or completely unknown events (unknown unknowns), events that were not on the list of known events from the perspective of those who carried out a risk analysis, and events on the list of known events in the risk analysis but found to represent a negligible risk (Aven and Krohn, 2014, p. 9).

Before the Dutch explorer Willem de Vlamingh discovered Australia in 1697, Europeans believed that all swans were white. However, Vlamingh noticed dark black swans that were as remarkable as white swans, and therefore it paved the way Europeans to concentrate on the concept of "black swans" (Taleb, 2007, p.15; Blight and Lang, 2013, p.4; Gardner, 2017, p.3; Roland, 2017, p.823; Santoli and Siebenbrunner, 2018, p.2). In addition to that, although two months prior to 9/11, The New York Times carried an article stating that the terror threat was actually on a decline and no longer widespread, and the United States of America was a superpower in the security context worldwide, the suicide attacks targeted World Trade Center that was called as "September 11 Attacks" reveal the significance of black swan metaphor (Aik and Xiang, 2016, p.61).

All organizations face risks such as operating risk, market risk, financial risk, and strategic risk. To address and manage these risks most organizations have a risk management function. However, this risk management function generally addresses the "known" financial, operational, and strategic risks via different methods. While significant effort is expended to mitigate these "known" risks, little effort is expended concerning "unknown" risks, containing catastrophic and strategic risks (Petty, 2012, p.21). Thus, these cause blindness specifically to unknown risks. In this sense, blindness to the black swan arise in these conditions below as Taleb $(2007$, p.50) states:

- Concentrating on preselected segments of the seen and generalize from it to the unseen; namely, the error of confirmation,

- Narrative fallacy and tunnel vision, 
- Considering the black swan that it does not exist, as it is in human nature,

- Ignoring silent evidence.

Taking into consideration the significance of managing black swans, it has been foreseen that, being avoided unrealistic expectations, developed strategies via clearly determining and understanding of the space of possibilities in the planning and managing risks, analyzed both internal and external environment via being aware of black swans for preventing black swan blindness, formulated strategies within the awareness of taking into account every possibilities via avoiding the creation of strategies with dogmatical perspective, and befriended with positive black swans and taken necessary measures via behaving proactive to negative black swans will play a crucial role in organizations' success and sustainability.

\section{Kaynakça / References}

Aik, L. G. S., ve Xiang, M. S. Y. (2016). Black Swans need not be black: Preparing the RSAF to succeed in spite of future uncertainties. Beyond the Horizon: Forging the Future RSAF, 60-74.

Andersen, M. M., ve Poulfelt, F. (2014). Beyond strategy: The impact of next generation companies. UK: Routledge.

Arnas, N. (2009). Fighting chance: Global trends and shocks in the national security environment. USA: Potomac Books.

Aven, T. (2015). Implications of black swans to the foundations and practice of risk assessment and management. Reliability Engineering \& System Safety, 134, 83-91.

Aven, T. (2017). A conceptual foundation for assessing and managing risk, surprises and black swans. In the Illusion of Risk Control, 23-39.

Aven, T., ve Krohn, B. S. (2014). A new perspective on how to understand, assess and manage risk and the unforeseen. Reliability Engineering $\mathcal{E}$ System Safety, 121, 1-10.

Baumard, P., ve Starbuck, W. H. (2005). Learning from failures: Why it May not happen. Long Range Planning, 38(3), 281-298. doi:10.1016/j.lrp.2005.03.004

Blight, J. G. ve Lang, M. J. (2013). Black swans/White House: Why JFK matters a half century after dallas. CIGI Papers Series, 5, 1-12

Bogle, J. C. (2008). Black monday and black swans. Financial Analysts Journal, 64 (2), 30-40. 
Brunåker, F., ve Nordqvist, A. (2013). A performance evaluation of black swan investments. Bachelor Thesis, 15 ECTS.

Catalano, A. S., Redford, K., Margoluis, R., ve Knight, A. T. (2017). Black swans, cognition, and the power of learning from failure. Conservation Biology, 32 (3), 584-596.

Flage, R., ve Aven, T. (2015). Emerging risk-conceptual definition and a relation to black swan type of events. Reliability Engineering \& System Safety, 144, 61-67.

Forsman, E. (2018). Black swan: Synthesis and future research directions. Master's Thesis in Strategic Business Development.

Gardner, M. G. (2017). Trucking, black swans and safety. Executive White Paper, 1-9.

Hajikazemi, S., Ekambaram, A., Andersen, B., ve Zidane, Y. J. (2016). The black swan-knowing the unknown in projects. Procedia-Social and Behavioral Sciences, 226, 184-192.

Indris, S., ve Primiana, I. (2015). Internal and external environment analysis on the performance of small and medium industries (SMEs) in Indonesia. International Journal of Scientific \& Technology Research, 4(4), 188-196.

Karadimas, A., Hewig, E., Behera, S., ve Kotisi, T. A. (2014). Case study of black swans and antifragility. Semantic Scholar, 1-17.

Kennon, D., ve Schutte, C. S. (2015). A strategic framework for improbable circumstances. South African Journal of Industrial Engineering, 26(2), 68-84.

Lindaas, O. A., \& Pettersen, K. A. (2016). Risk analysis and black swans: Two strategies for de-blackening. Journal of Risk Research, 19(10), 1231-1245.

Mahroum, S. (2015). The Foolhardy Quest for a European Google. In CESifo Forum, 16(2), 48-49.

Maslen, S., ve Hayes, J. (2015). Preventing black swans: Incident reporting systems as collective knowledge management. Journal of Risk Research, 19 (10), 1246-1260.

Masys, A. J. (2012). Black swans to grey swans: Revealing the uncertainty. Disaster Prevention and Management: An International Journal. 21(3), 320-335.

Mezias, J., ve Starbuck, W. H. (2008). Decision making with inaccurate, unreliable data. The Oxford Handbook of Organizational Decision Making. Oxford University Press.

Mueller, J., ve Stewart, M. G. (2016). The curse of the black swan. Journal of Risk Research, 19(10), 1319-1330.

Nafday, A. M. (2009). Strategies for managing the consequences of black swan events. Leadership and Management in Engineering, 9(4), 191-197. 
Peters, D. A., ve McKay, D. A. (2014). Why won't my financial advisor beat the market? Reflections on the 'black swan'. Plastic Surgery, 22(3), 213-214.

Petty, M. (2012). The dark side of leadership: Catastrophic failure. Strategic Leadership Review, 1(1), 20-29.

Ponkin, I. V. (2019). Black swan event as manifestation of uncertainties in public administration. Mediterranean Journal of Social Sciences, 10(2), 9-15.

Poonawala, M. S. (2016). Black swans - from expecting risk to expanding technology. ISACA Journal, 3, 1-4.

Roland, D. (2017). Spotting the black swan: Why emergency medicine is ahead of the curve. Emergency Medicine Journal, 34 (12), 823-824.

Runde, J. (2009). Dissecting the black swan. Critical Review, 21(4), 491-505.

Santoli, T., ve Siebenbrunner, C. (2018). An ontological investigation of unimaginable events. Cornell University, 1-18.

Sarriot, E. (2009). Black swans, grey swans, sustainability. Or, the difference between planning and predicting. SHOUT Group, 1-15

Stodd, J., Reitz, E. A., Schatz, S., ve Fautua, F. (2016). Black swans and the limits of hierarchy. Proceedings of the I/ITSEC 2016, 1-12.

Taleb, N. N. (2007). The black swan: The impact of the highly improbable. USA: Random House.

Taleb, N. N., ve Blyth, M. (2011). The black swan of Cairo: How suppressing volatility makes the world less predictable and more dangerous. Foreign Affairs, 90(3), 33-39.

Van Dyck, C., Frese, M., Baer, M., ve Sonnentag, S. (2005). Organizational error management culture and its impact on performance: A two-study replication. Journal of Applied Psychology, 90 (6), 1228-1240.

\section{Kaynakça Bilgisi / Citation Information}

İnce, M. ve Özbozkurt, O. B. (2020). Siyah kuğuyu yönetmek. OPUSUluslararası Toplum Araştırmaları Dergisi, 15(23), 2177-2178. DOI: 10.26466/opus.686105 